\title{
РЕКРЕАЦИОННОЕ РАЙОНИРОВАНИЕ ТЕРРИТОРИИ ВОСТОЧНО-КАЗАХСТАНСКОЙ ОБЛАСТИ
}

\author{
3. Е. Намазбаева, А. С. Актымбаева \\ Университет Нархоз, Казахстан \\ Казахский наџиональный университет им. аль-Фараби, Казахстан \\ Поступила в редакцию 26 ревраля 2019 г.
}

\begin{abstract}
Аннотация: В статье рассматривается туристский потенциал Восточно-Казахстанской области (ВКО). На основе комплексного исследования предлагается районирование территории по степени аттрактивности природных ландшафтов и районирование по степени насыщенности социально-экономическими туристско-рекреационными ресурсами. Выявлен совокупный туристско-рекреационный потенциал Восточного Казахстана и предложены концептуальные направления развития перспективных видов туризма.
\end{abstract}

Ключевые слова: ВКО, аттрактивность, районирование, туристско-рекреационный потенциал.

\section{Recreational zoning of the territory of the East Kazakhstan region}

\section{Z.E. Namazbayeva, A.S. Aktymbayeva}

Abstract: The article discusses the tourist potential of the East Kazakhstan region. Based on a comprehensive study, zoning of the territory is proposed according to the degree of attractiveness of natural landscapes and zoning according to the degree of saturation with socio-economic tourist and recreational resources. The cumulative tourist and recreational potential of East Kazakhstan is revealed and conceptual directions of development of promising types of tourism in the region are proposed.

Key words: East Kazakhstan, attractiveness, zoning, tourist and recreational potential.

\section{ВВЕДЕНИЕ}

В настоящее время в Казахстане особое внимание стали уделять проблемам развития туризма. Свидетельством тому является принятый в 2015 году «План нации - 100 конкретных шагов по реализации пяти институциональных реформ». Согласно Плану, заложено несколько государственных проектов, направленных на повышение конкурентоспособности туристской отрасли. В соответствие с 57-м шагом Плана предвидится привлечение стратегических (якорных) инвесторов, имеющих определенный опыт формирования успешных туристских кластеров [6]. Приоритетной задачей политики государства является создание условий для развития внутреннего туризма, что связанно с удовлетворением потребностей казахстанцев в отдыхе и оздоровлении, используя внутренний туристско-рекреационный потенциал страны.

(C) Намазбаева 3.Е., Актымбаева А. С., 2019

(c) (1) Материал статьи доступен по лицензии Creative Commons "Attribution" 4.0
ВКО по праву считается одним из перспективных регионов Казахстана для развития туризма. Обладая выгодным географическим и геополитическим положением, большим разнообразием природных ресурсов, природно-климатической спецификой, уникальным культурно-историческим наследием, транспортной доступностью, наличием специализированных образовательных учреждений, область имеет все предпосылки для развития внутреннего и въездного туризма. Она может рассматриваться как наиболее перспективный рекреационный регион Казахстана.

\section{ОБЪЕКТЫ И МЕТОДЫ ИССЛЕДОВАНИЯ}

Методы исследования: статистический, картографический, аналитический. Целью исследования является определение направлений развития внутреннего туризма в ВКО на базе комплексного рекреационного районирования территории.

Восточно-Казахстанская экономическая зона состоит из одной административной области - Восточно-Казахстанской. Общая площадь Восточного Казахстана составляет 283,2 км² (самая малая эконо- 
мическая зона в Казахстане). Население Восточного Казахстана составляет более 1 млн 383,7 тыс. человек. Этот регион занимает третье место по численности населения среди других территорий республики. На население Восточного Казахстана приходится приблизительно 9,1\% от общей численности населения Казахстана. Усть-Каменогорск - самый крупный город в регионе с населением в 298100 чел. Эта область расположена на крайнем востоке страны - на стыке с Китаем, Монголией и Россией. Большая часть территории состоит из высоких горных гряд Алтая, Калбы и Саур-Тарбагатая. Высота гор достигает 3000-4000 м. Основные реки - Ертис, Оба и Ульба. Самые крупные озера в регионе - Маркаколь, Жайсан, Алаколь и Сасыкколь. Климат резко континентальный с широкими колебаниями температуры воздуха [8]. Ландшафты равнин чередуются с горными ландшафтами. Песчаные пустыни, глинистые каньоны, равнинные и горные степи, лиственные леса, альпийские луга и горные пики высотой до 4500 м над уровнем моря (наивысшая точка Алтайских гор - г. Белуха) - типичные ландшафты ВосточноКазахстанской области. Здесь функционируют центры отдыха (Бухтарминский берег, Сибинские озера, Белуха, Маркаколь, Синяя бухта, Риддер), пункты организации туристских походов и прогулок на лошадях, создана инфраструктура для занятий рафтингом, плаванием и рыбной ловлей. Открыты 62 источника подземных вод, четыре из которых используются для лечения на бальнеологических курортах. территория охватывает часть АлтайСаянской экозоны Казахстана - одной из 200 приоритетных экосистем по классификации Всемирного фонда дикой природы, признанной ЮНЕСКО в качестве особой заповедной зоны.

В отношении туристских достопримечательностей особого внимания заслуживают Курчумский и Катон-Карагайский районы, окрестности городов Риддер и Усть-Каменогорск, озера Алаколь и Зайсан, а также берег реки Бухтарма [7]. Для сохранения уникальной природы ВКО создана сеть особо охраняемых природных территорий республиканского значения: три заповедника, один национальный парк и природный резерват, восемь ботанических и зоологических заказников, шесть памятников природы, пять водоемов, имеющих важное государственное значение или особую научную ценность. Их площадь составляет 1784536 га, из них 50811 га заняты водоемами, 641258 га покрыты лесом [1, 2].
Область отличается многими природными, историческими и культурными памятниками - гора Белуха (самый высокий пик Алтая и всей Сибири), озеро Маркаколь и водопад Кокколь, захоронения Берель и музейный комплекс Абай. Наиболее привлекательными ресурсами для иностранных туристов являются горы ВКО. В области активно работают семьдесят две туристские организации, семнадцать санаториев и оздоровительных учреждений, 90 гостиниц, 8 детских оздоровительных учреждений, пятнадцать турбаз, пятнадцать кемпингов. Действуют 11 музеев с 276700 экспонатами, драматический театр им. Жамбыла на 297 мест, четыре мультиплекса, театр-сервис Жаналык на 500 посадочных мест. Четыре компании организуют концерты. Функционируют 183 клуба и парк развлечений, 14 зон досуга и зоопарк. В общей сложности в области 595 памятников исторического, архитектурного и культурного значения, которые представляют интерес для посетителей.

По методике М. Милеской авторами проведена классификация типов природных ландшафтов по 15 административным районам Восточного Казахстана [3]. Оценивались типы ландшафтов, объекты природно-заповедного фонда, месторождения минеральных вод, промысловые виды животных и другие природные объекты, имеющие туристскую привлекательность.

\section{РЕЗУЛЬТАТЫ ИССЛЕДОВАНИЯ}

Авторами выделено четыре района с разной степенью туристской аттрактивности по шкале ценности от 1 до 4 пунктов. Система оценивания природных условий и ресурсов дает возможность сравнить различные территории и показать их потенциал для развития массовых видов туризма [5]: весьма благоприятные - 4 балла (Катонкарагайский район); благоприятные - 3 балла (Кокпектинский, Алтай, Курчумский, Тарбагатайский районы); малоблагоприятные - 2 балла (Глубоковский, Абайский, Аягозкий, Жарминский, Зайсанкий, Бескарагайский, Уланский, Уржарский, Бородулихинский, Шемонаихинский районы); неблагоприятные - 1 балл.

Нами составлена карта «Районирование территории Восточного Казахстана по степени аттрактивности природных ландшафтов» (рис. 1), которая дает представление о районах сосредоточения природных рекреационных ресурсов.

На основе физико-географического подхода авторами выделены группы ландшафтов Восточного Казахстана по следующим критериям: рек- 


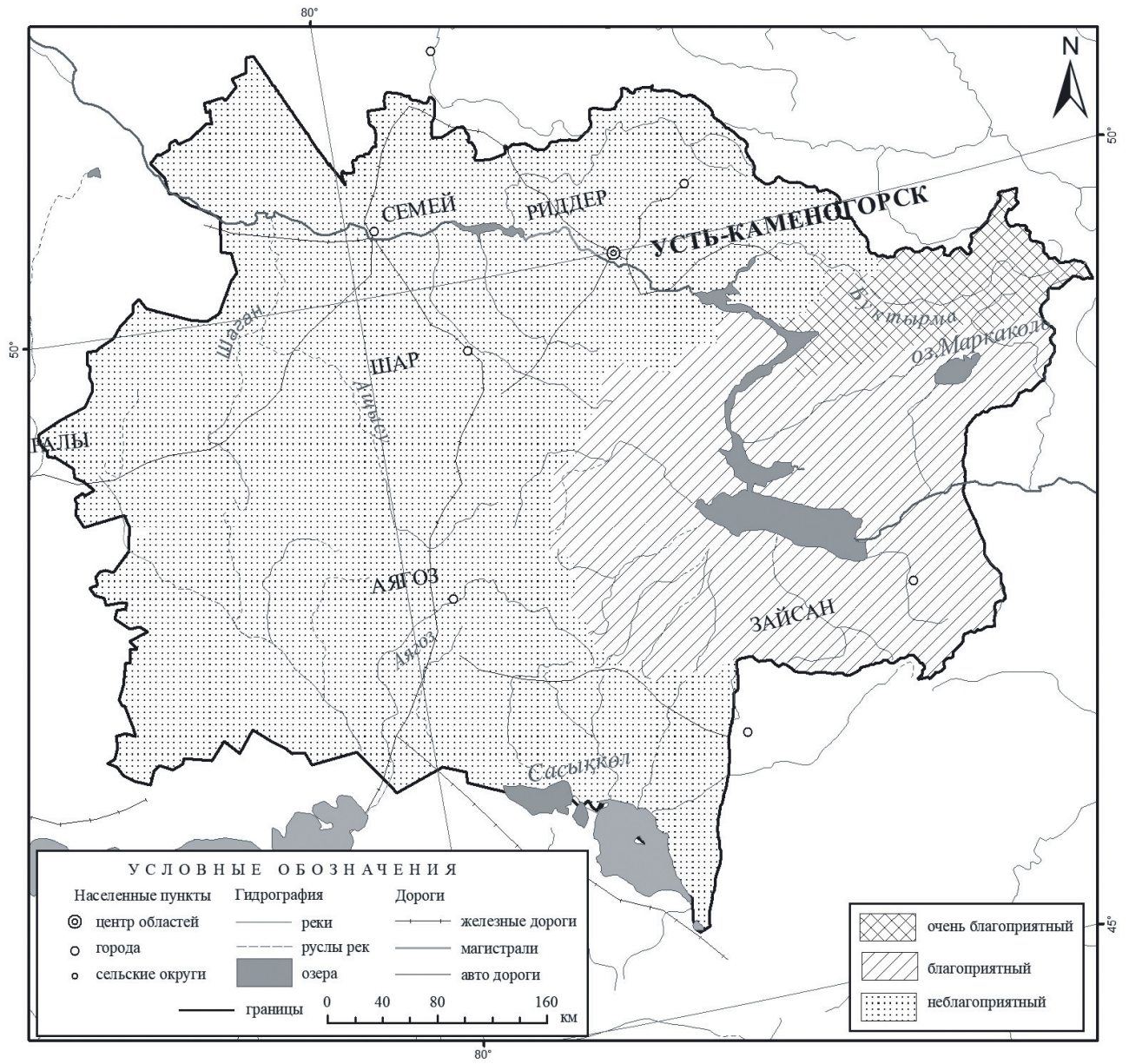

Puc. 1. Районирование территории Восточного Казахстана по степени аттрактивности природных ландшафтов [составлена авторами]

реационное качество и возможность осуществления разнообразных видов отдыха и туризма.

1. Ландшафты с весьма благоприятными условиями для длительного и всех видов кратковременного отдыха (3 балла). Согласно исследованиям, для организации летних и зимних видов туризма благоприятны низкогорные лесные ландшафты темнохвойной тайги и лиственничные леса Казахстанского Алтая и Саура, перевалы Мраморной горы, хребет Азутау, Маркакольская впадина.

2. Ландшафты с выборочно благоприятными условиями (2 балла) для всех видов кратковременного индивидуального и массового отдыха. Особо значимы низкогорные и мелкосопочные степные ландшафты Казахской складчатой страны.

3. Ландшафты с малоблагоприятными условиями для отдыха (1 балл). Сформированные лесостепными, сухостепными мелкосопочными, сухостепными равнинными, полупустынно-мелкосопочными и полупустынно-равнинными ландшафтами, размещенные в пределах части Сибирской равнины, Атбасарской сухостепной равнинной провинции, Тенизской впадины.

Основными составляющими природно-рекреационного потенциала ВКО являются благоприятные для курортного лечения климатические условия и живописные сочетания рельефа, озер, сосново-березовых и сосновых лесов, их сезонная комфортность для любых видов туристско-рекреационной деятельности.

По состоянию на 2008 год в «Списке памятников истории и культуры местного назначения ВКО» числятся 595 наименований, шестнадцать из которых республиканского значения [5]. В области насчитывается 320 памятников археологии. С привлечением зарубежных ученых ведутся масштабные археологические раскопки на знаменитом комплексе Берельские курганы (Катон-Карагайский район), в Шиликтинской долине, где находятся более 350 курганов (Зайсанский район), буддийском монастыре Аблайкет (Уланский район), могильниках Кырыкунгир (Абайского района), и Еле- 


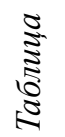

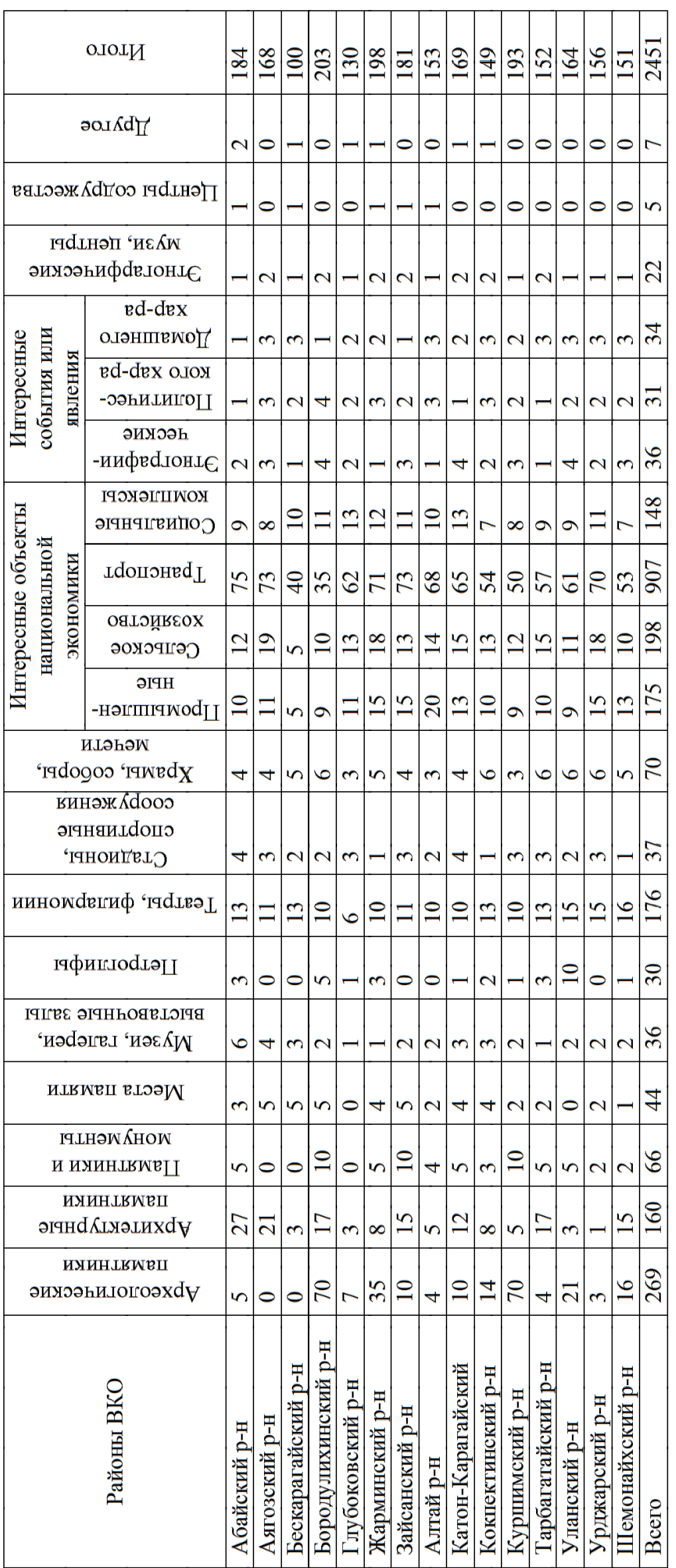




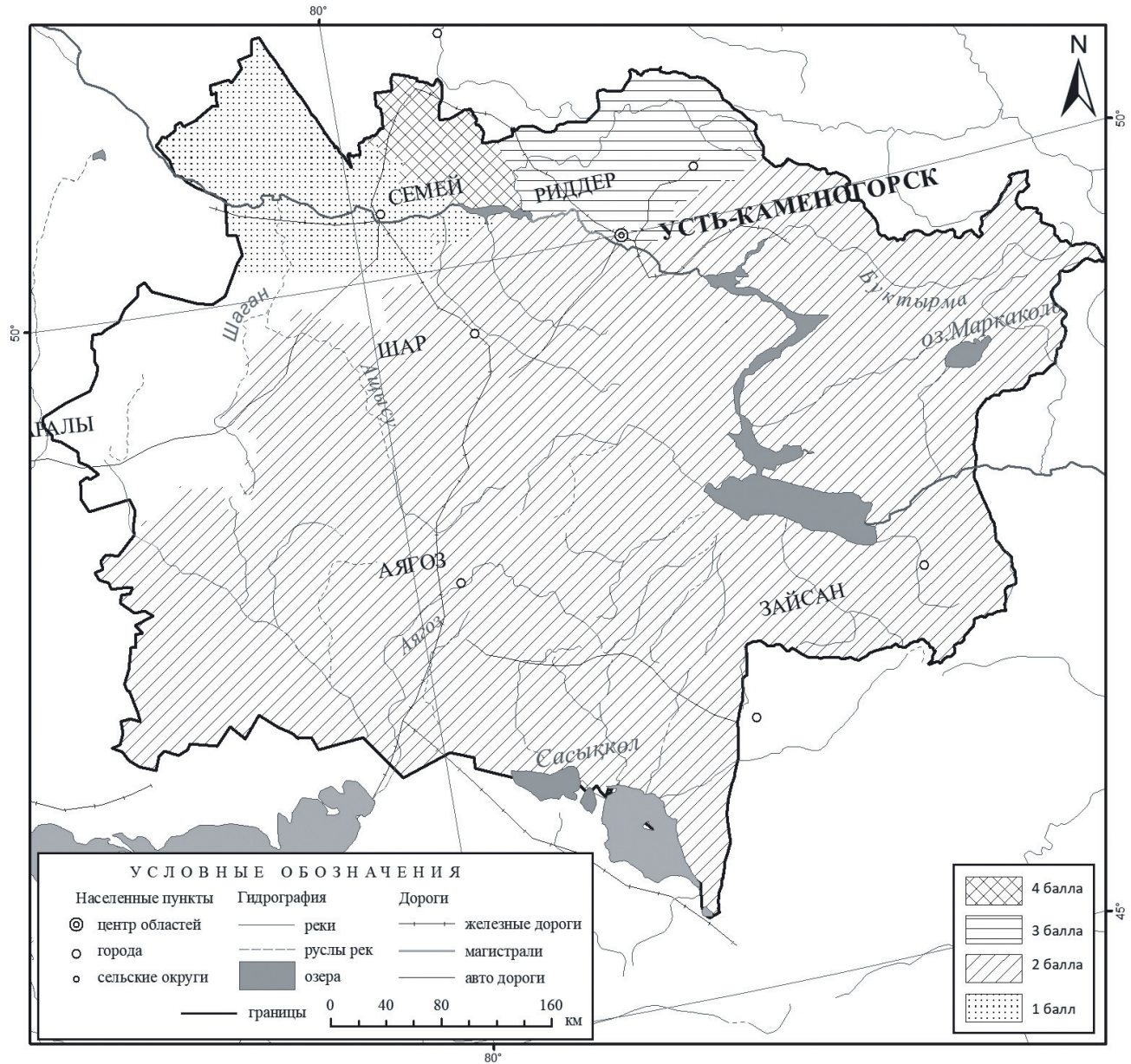

Puc. 2. Районирование территории Восточного Казахстана по степени насыщенности социально-экономическими туристско-рекреационными ресурсами [составлено авторами]

ке сазы (Тарбагатайский район) [4]. Наряду с этим открыты для показа дома-усадьбы, архитектурные ансамбли, культовые сооружения, памятники монументального искусства и другие объекты, выступающие основой культурно-познавательного туризма.

По итогам проведенных исследований был выявлен уровень насыщенности территории ВКО культурными и историческими памятниками на основе их переписи (таблица). Собранные материалы были использованы для составления авторской карты «Районирование территории Восточного Казахстана по степени насыщенности социально-экономическими туристско-рекреационными ресурсами» (рис. 2).

Согласно рисунку 2, наиболее насыщенным является Бородулихинский район, оцененный в 4 балла, с количеством 203 объектов; Алтай, Абайский, Катон-Карагайский, Жарминский, Аягозский, Курчумский, Уланский, Зайсанский, Уржарский, Тарбагатайский районы - 3 балла, с количеством от 152 до 202 объектов; Глубоковский, Ше- монаихинский районы - 2 балла, с количеством от 101 до 151 объекта; Бескарагайский район 1 балл, с количеством до 100 объектов.

Среди городов выделяются Оскемен, Семей, Алтай, где значимы, в основном, памятники монументального искусства.

При оценке совокупного туристско-рекреационного потенциала была построена обобщающая шкала, ранжированная на интервалы, на основе которой составлена картограмма «Совокупный туристско-рекреационный потенциал развития туризма на территории Восточного Казахстана» (рис. 3).

Данная картограмма показывает, что наиболее высоким потенциалом обладает территория Катон - Карагайского и Уржарского районов, оцененная максимальным количеством баллов - 10; средним потенциалом, т.е. получившим 7 баллов, обладают Абайский, Аягозский, Кокпектинский, Бородулихинский, Курчумский, Жарминский, Тарбагатайский, Глубоковский, Зайсанский, Алтай, Уланский, Шемонаихинский районы; невысоким потенциа- 


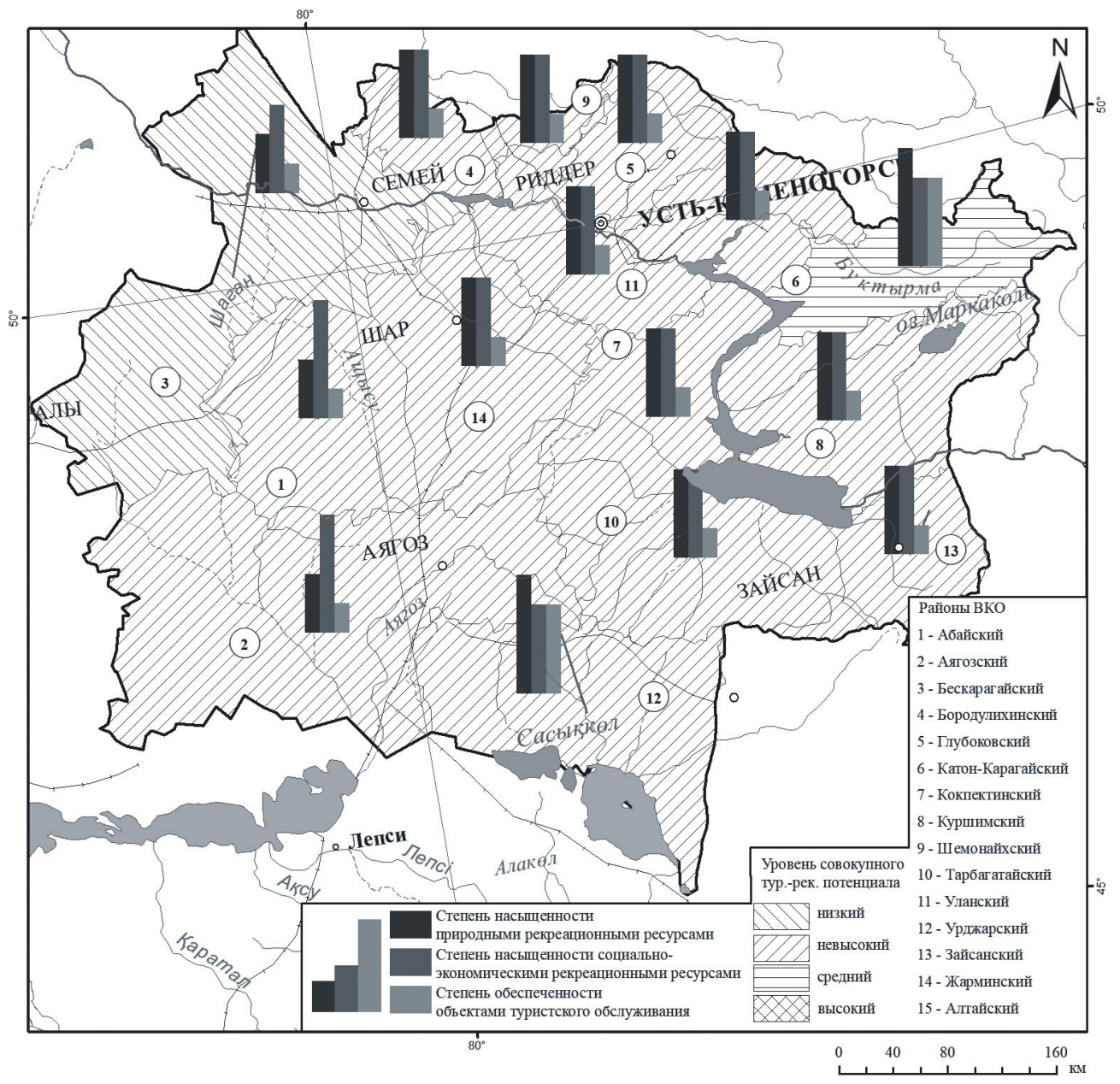

Puc. 3. Совокупный туристско-рекреационный потенциал Восточного Казахстана [составлено авторами]

лом, который соответствует 6 баллам, обладает Бескарагайский район.

Как видно из рисунка 3, северная и восточная части области являются благоприятными зонами для развития рекреационной деятельности.

Рекреационный потенциал позволяет оценивать возможность и целесообразность освоения тех или иных территорий, представляющих интерес для рекреационной деятельности, позволяющих сохранить уникальность и разнообразие естественных ландшафтов.

\section{ВЫВОДЫ}

На основе проведенного исследования нами определены следующие перспективные виды туризма для территории ВКО.

1. Катон - Карагайский и Уржарский районы, выявленные как территории с наиболее ценными и уникальными туристско-рекреационными ресурсами, могут быть использованы для развития купально-пляжного, сакрального, культурно-познавательного, научного, лечебно-оздоровительного туризма, туризма наследия. Неограниченны возможности развития экотуризма и агротуризма.
2. Двенадцать районов области или $83 \%$ территории обладают средней рекреационной ценностью. Данные районы могут быть ориентированы на развитие природно-ориентированного, приключенческого, охотничьего туризма (в отдаленных и труднодоступных местностях). На востоке и юговостоке области имеются необходимые природные и инфраструктурные условия для возрождения активных видов отдыха: горнолыжного и спортивного туризма. В силу исторических событий прошлого века имеются большие возможности для развития этнографического (этнического и ностальгического) туризма. Наличие историко-археологических объектов позволяет активно развивать познавательный и научный туризм.

3. Бескарагайский район - территория с ограниченными или непривлекательными туристскорекреационными ресурсами. Туризм здесь должен развивается в соответствии с потребностями местного населения (аграрный, основанный на сообществах, этнографический туризм).

Таким образом, территория Восточного Казахстана обладает высоким потенциалом для разви- 
тия туризма. Это обусловлено наличием большого количества рекреационных ресурсов и благоприятными условиями низкогорных лесных ландшафтов.

\section{СПИСОК ЛИТЕРАТУРЫ}

1. Агентство Республики Казахстан по статистике. - URL: http://stat.gov.kz/faces/homePage (дата обращения 27.06.2018).

2. Кабдрахманова А. М. Развитие туризма в Восточно-Казахстанской области / А. М. Кабдрахманова // Научное сообщество студентов XXI столетия. Экономические науки : сборник статей по материалам XIV Международной студенческой научно-практической конференции. - URL: http://sibac.info/archive/ economy/14.pdf (дата обращения: 11.07.2018).

3. Милеская М. И. Классификация туристских местностей / М. И. Милеская. - Москва : Земля, 1967. T. 3. $-230 \mathrm{c}$.

4. Намазбаева 3. Е. Мультипликативный эффект развития туристско-рекреационной деятельности Восточно-Казахстанской области / 3. Е. Намазбаева // Вестник Ошского государственного университета. Сер. Естественные науки. - 2018. - № 3. - С. 7-11.

5. Об утверждении государственного списка памятников истории и культуры местного значения. - URL: http://egov.kz/cms/ru/law/list/V08V0002484 (дата обращения 15.01.2019).

6. План нации - 100 конкретных шагов по реализации пяти институциональных реформ Главы государства Нурсултана Назарбаева (май 2015 года). - URL: https://online.zakon.kz/ Document/?doc_id=31977084\#pos =4;-163 (дата обращения: 12.09.2018).

7. Разработка концепции регионального развития и территориальной организации внутренного туризма Республики Казахстан : отчет ПФИ / С. Р. Ердавлетов [и др.]; НИИ проблем экологии, МОН РК. - Алматы, 2013. - C. 99-106.

8. Социально-экономический паспорт ВосточноКазахстанской области за 2017 год. - URL: http:// www.akimvko.gov.kz/ru/region/ (дата обращения 11.07.2018).

\section{REFERENCES}

1. Agentstvo Respubliki Kazakhstan po statistike (Agency of the Republic of Kazakhstan on statistics), Available

Намазбаева Зауре Есенкуловна

старший преподаватель $\mathrm{AO}$ «Университет Нархоз», г. Алматы, Казахстан, E-mail: zaure.namazbaeva@ narxoz.kz

Актымбаева Алия Сагындыковна

кандидат географических наук, доцент Казахского национального университета им. аль-Фараби, г. Алматы, Казахстан, E-mail: aliyaaktymbayeva@gmail.com at: http://stat.gov.kz/faces/homePage (accessed 27 June 2018).

2. Kabdrakhmanova A. M., Razvitie turizma v Vostochno-Kazakhstanskoy oblasti [Tourism development in the East Kazakhstan region]. Nauchnoe soobshchestvo studentov XXI stoletiya. Ekonomicheskie nauki : sbornik statey po materialam XIV Mezhdunarodnoy studencheskoy nauchno-prakticheskoy konferentsii (Scientific community of students of the XXI century. Economic sciences: a collection of articles based on the materials of the XIV International Student Scientific and Practical Conference), Available at: http://sibac.info/archive/economy/14.pdf (accessed 11 July 2018).

3. Mileskaya M. I., Klassifikatsiya turistskikh mestnostey [Classification of tourist areas]. Moscow : Zemlya, 1967, Vol. 3, $230 \mathrm{p}$.

4. Namazbaeva Z. E., Mul'tiplikativnyy effekt razvitiya turistsko-rekreatsionnoy deyatel'nosti Vostochno-Kazakhstanskoy oblasti [The multiplicative effect of the development of tourist and recreational activities of the East Kazakhstan region]. Vestnik Oshskogo gosudarstvennogo universiteta. Ser. Estestvennye nauki, 2018, No. 3, pp. 7-11.

5. Ob utverzhdenii gosudarstvennogo spiska pamyatnikov istorii i kul'tury mestnogo znacheniya [On approval of the state list of historical and cultural monuments of local importance]. Available at: http://egov.kz/cms/ru/law/list/ V08V0002484 (accessed 15 January 2019).

6. Plan natsii, 100 konkretnykh shagov po realizatsii pyati institutsional'nykh reform Glavy gosudarstva Nursultana Nazarbaeva (may 2015 goda) [The nation's plan 100 concrete steps to implement the five institutional reforms of the Head of State Nursultan Nazarbayev (May 2015)]. Available at: https://online.zakon.kz/ Document/ ?doc_id=31977084\#pos=4;-163 (accessed 12 September 2018).

7. Erdavletov S. R.. and etc., Razrabotka kontseptsii regional'nogo razvitiya i territorial'noy organizatsii vnutrennogo turizma Respubliki Kazakhstan : otchet PFI, [Development of the concept of regional development and territorial organization of domestic tourism of the Republic of Kazakhstan: PFI report]. Almaty, NII problem ekologii, MON RK, 2013, pp. 99-106.

8. Sotsial'no-ekonomicheskiy pasport Vostochno-Kazakhstanskoy oblasti za 2017 god [Socio-economic passport of the East Kazakhstan region for 2017]. Available at: http://www.akimvko.gov.kz/ru/region/ (accessed 11 July 2018).

Namazbayeva Zaure Esenkulovna

Senior lector at the JSC «Narhoz University», Almaty, Kazakhstan, E-mail: zaure.namazbaeva@ narxoz.kz

Aktymbayeva Aliya Sagyndykovna

$\mathrm{PhD}$ in Geography, Associate Professorof the Kazakh National University named after al-Farabi, Almaty, Kazakhstan, E-mail: aliyaaktymbayeva@gmail.com 